\title{
National taxation policies dynamics in agrarian industry globalization: assessing the efficiency factors
}

\author{
Prateep Wajeetongratana ${ }^{1, *}$ \\ ${ }^{1}$ FMS, Suan Sunandha Rajabhat University, 1 U-Thong Nok rd, 10200, Dusit, Bangkok, Thailand
}

\begin{abstract}
This research study takes up the criteria of comfortable/harsh national taxation policies in an attempt to analyze various impacts of countries' tax systems on their macroeconomic growth as well as on countries' participation in the world economic processes. More specifically, the article analyzes the correlation between the dynamics of tax regimes' components on the one side and the macroeconomic indicators of countries on the other, while the authors present their own, original classification of the countries divided into groups depending on the level of their wellbeing. Further on, authors' conclusions are focused around the efficiency of fiscal instruments in part of economic growth stimulation and trade attractiveness. These conclusions are generally applicable to the majority of today's countries. Also, the study shows how tax policies and tax regimes (de)stimulate economic growth and increase/decrease trade attractiveness of different countries in today's globalized world. This obviously proves that taxation overall has enough power to affect national macroeconomic growth in general and foreign trade in particular. Indirectly, it also has the power to affect social wellbeing and the state of national infrastructure.
\end{abstract}

\section{Introduction}

In any country, developed or developing one, the key role of taxes is to regulate the market, keep market ups and down balanced and make sure income distribution within the society is relatively fair. Through all of the above taxes and tax system are pushing country's economic development forward. This is especially applicable to emerging economies, as for them, ongoing economic growth is the key survival factor. Thus, all the accompanying issues around tax policies and tax regime are stably of interest for both public economists and independent researchers, in both developing and developed countries.

Today quite many international organizations and cross-country research groups are involved in international and regional research projects measuring and comparing taxation rates and overall comfort of tax regimes across countries (or regions). In fact, this crosscountry comparison of taxation conditions is often further used for ranking countries in that

*Corresponding author: prateep.wa@ssru.ac.th 
way or another. In other words, tax conditions in a country are integral part of international competitiveness evaluation. Moreover, description of current tax conditions in a country often forms the basis for further economic forecasts, strategic planning, public development programs and the like.

Stemming from all above, our central research objective here can be formulated as follows: to take up and operate the most common tax indicators along with macroeconomic indicators for a sample of selected countries and then to assess the (potential) impact of tax policies and tax conditions on economic development rates of these selected countries.

Additionally, we put forward several supplementary tasks:

- to detect the correlation (if any) between national tax conditions and foreign trade success of a country;

- to determine whether country's indicators as per "Doing Business" have any meaningful correlation with country's success in export and import;

- to prove that in relation to country's economic growth overall the tax rate size is significantly more important than the ease and the transparency of all taxation procedures;

- to investigate whether a reverse correlation is applicable here: national economic growth impact foreign trade and future tax conditions in a country.

\section{Literature Overview}

Key specific features of national taxation policies and of national tax strategies were very well described by H. Pemberton [1]. This author examined quite an array of new taxes' implementation from the 1960s and on, analyzing the core elements of national growth policies. Pemberton emphasized, inter alia, that such policy changes were expected to boost growth through solid governmental control over the economy, thus encouraging more productive use of labour resources and investment incentives.

S. Acharya [2] saw taxation as one of the central elements in a national economic policy, developing in the context of ongoing global economic liberalization.

F. Widmalm [3] analyzed cross-sectional data across two dozens of countries and three decades (till 1990) and came to the conclusion that the structure of a taxation system nearly always has an immediate effect on economic growth. The key conclusions of this author was that extra tax revenues generated through personal income taxes (nearly) always have a strongly negative correlation with economic growth of a country. Moreover, the author insisted that progressive taxation scale inevitably leads to delayed economic growth.

Among Eastern European studies on correlation between economic growth and taxation reforms as applied to regional developing economies we would like to mention E.V. Balatskii [4]. The author came up with his own and rather original explanation of the adverse influence of taxation reforms on economic development of transit countries and also suggest his own classification of tax reforms, in which special place is assigned to the so-called quasi-traps and pseudo-traps.

Another interesting and also Eastern European study on the dependence between tax load and economic development in the countries of the region in question is the one offered by L. Sinevičiene [5]. The central conclusion of this study is: in more developed countries, tax load on capital and household consumption is officially higher than in developing ones, however, "hidden" taxes on capital are higher in developing countries with larger public sectors and significant size of government debt.

J. Vogel [6] investigated data on a wide range of European countries and then grouped them into three clusters - South, Central and North one - as per strategic guidelines in tax policies and practical methods used in taxation practice. This division into clusters also indirectly proves that there are different trends in the influence of national tax policies on social wellbeing in a country. 
$[7,8]$ took the case study of Switzerland and proved that in such a stable economy as Swiss one taxation policy has the capacity to boost economic growth even further. Moreover, in a longer term, it can lead to economic growth rate being as high as $4-5 \%$ per annum.

Studies on the role of taxation for economic development are present in nearly every country these days, however, US and EU studies are obviously leading in this direction, in terms of both theoretical and applied contributions. Among those, we could mention R. Hill [9], for example, as the study which has described several possible models of tax systems in their adaptation to strict requirements of economic growth. This author came to a rather interesting conclusion: there is hardly any correlation between economic growth and the size of the state, while economic growth and taxation rates have a strong correlation in nearly every case.

Another noteworthy study is the one by G.W. Scully [10]. This author has emphasized that separate categories of taxes have separate optimal rates and thus - very different influence on economic development of a country. Curiously $[11,12,13]$ chose to concentrate their attention strictly on personal income tax rates.

Despite all the variety of national, regional and international studies on these issues, we have found a research gap which we would like to fill, and this has become the key goal of the study presented below. We have decided to start our research from classifying countries into groups as per different levels of social wellbeing in them. Our second step will be to assess the efficiency of tax policy according to those classified groups. After that, we would like to attempt determining the causes-effects behind different results of these groups (and we are initially very much confident that their results will differ a lot).

\section{Research Methodology}

Since our study is essentially based on the most common indicators (tax rates, macroeconomic indicators), we have opted to make use of the most appropriate database for such a case - the World Bank database. More specifically, we are going to use the following parameters:

- GDP growth rates;

- GDP per capita;

- changes in export and import volumes (relative and absolute ones).

All of this data will be split as per countries' division into groups.

In our research and analysis we have been mostly operating the statistical information of the World Bank (from their official site - worldbank.org). From this large massive of data, we have extracted the needed information on the 150 countries of the world, the study period being from 2000 till 2017.

In order to determine the indicators of economic growth stability we have used the statistical method of mean-square deviation calculation in the indicators of economic growth dynamics as well as the indicators of national export and import growth for all the analyzed countries during these 15 years in question [14]. The obtained results are presented in Table 1.

As it is shown in Table 1, during the period of 2000-2017 the most stable economic growth has been demonstrated by the developing countries of Asia and Africa, and also by some developed - but noteworthy, distanced from the global economic processes and world turmoil overall Australia and Norway. Both these countries, apart from having powerful technological and industrial platforms for such an impressive economic growth, also have sufficient strategic reserves of natural raw materials. Among other developed countries rather stable economic growth has been observed in France, USA, Canada, Austria and Denmark. 
At the same time, economic growth stability of Japan turns out to be on the same level with Tunisia (a country still feeling the consequences of the severe political crisis), while the dynamic economic growth of India was rather unstable, thus, the indicator of this country turns out to be on the same level with Italian economy (the latter demonstrated mostly negative dynamics in the several recent years). The absolute leader in terms of economic growth stability during the first 15 years of the 21 century became Norway, while its closest geographical neighbor, Sweden, has found itself on the same level with Mexico and Brazil (the indicators of Finland are even lower). Most of fluctuations in economic growth among the well-to-do countries have been demonstrated by Ireland and Iceland. Countries, exporting raw materials (first of all - hydrocarbons) and thus having low diversification of their trade and economy overall, such as Azerbaijan, Nigeria, Russia and the United Arab Emirates - all find themselves in the last third of the list (100-150 ranks). Therefore, we can state that our hypothesis \#1 is confirmed.

Table 1. Proposed classification of countries for the purposes of this study (Proposed by the author).

\begin{tabular}{|c|c|c|c|}
\hline Groups & Group name & GDP per capita & $\begin{array}{c}\text { Number of countries in this } \\
\text { group }\end{array}$ \\
\hline 1 & Successful & Over $40,000 \$$ & 15 \\
\hline 2 & Developed & $25,000-39,999 \$$ & 15 \\
\hline 3 & Median & $15,000-24,999 \$$ & 20 \\
\hline 4 & Underachieving & $5,000-14,999 \$$ & 20 \\
\hline 5 & Needy & max. of $4,999 \$$ & 25 \\
\hline & Total: & & 95 \\
\hline
\end{tabular}

Besides, we have also borrowed some official data from the well-known Doing Business report. More specifically, we extracted such data:

- the ranking of taxation system in a country;

- the number of tax reporting per year;

- overall time required to do all necessary taxes;

- the averaged volume of all taxes per year ("averaged" here means average tax rate calculated for all categories of legal bodies and all types of businesses).

Thus, using the World Bank data and the Doing Business data taken together, we have investigated 95 countries (see Table 1 for division into groups). Division into those groups have been carried out by the authors as per their wellbeing level. The time framework of our study covers the period from 2010 till 2017.

\section{Research results and discussion}

The results of our correlation analysis show that the Doing Business rank of a country's tax system indeed has quite an obvious impact on the indicator of GDP per capita, and this impact seems to be a long-term one, that is, stable in years (see Table 2 for details). Improvement in this rank also has a strong influence on the growth in GDP per capita, however, this influence seems to be rather short-term, it tends to go down in 2-5 years after a country's improvement in this particular rank.

Table 2. Correlation between "Doing Business" ranking of a tax system and country's GDP per capita (Calculated by the authors on the basis of the World Bank and Doing Business data).

\begin{tabular}{|c|c|c|c|c|c|c|c|}
\hline \multirow{2}{*}{ Ranking } & \multicolumn{7}{|c|}{ GDP per capita } \\
\cline { 2 - 8 } & $\mathbf{2 0 1 1}$ & $\mathbf{2 0 1 2}$ & $\mathbf{2 0 1 3}$ & $\mathbf{2 0 1 4}$ & $\mathbf{2 0 1 5}$ & $\mathbf{2 0 1 6}$ & $\mathbf{2 0 1 7}$ \\
\hline 2010 & 0.55 & 0.55 & 0.56 & 0.56 & 0.55 & 0.56 & 0.56 \\
\hline
\end{tabular}




\begin{tabular}{|l|l|l|l|l|l|l|l|}
\hline 2011 & & 0.55 & 0.55 & 0.55 & 0.55 & 0.55 & 0.55 \\
\hline 2012 & & & 0.54 & 0.54 & 0.54 & 0.54 & 0.55 \\
\hline 2013 & & & & 0.54 & 0.54 & 0.54 & 0.54 \\
\hline 2014 & & & & & 0.55 & 0.55 & 0.55 \\
\hline 2015 & & & & & & 0.55 & 0.55 \\
\hline 2016 & & & & & & & 0.53 \\
\hline
\end{tabular}

Table 3. Correlations between the tax policy rating and national export-import volume (Calculated by the authors on the basis of the World Bank and Doing Business data).

\begin{tabular}{|c|c|c|c|c|c|c|}
\hline \multirow{2}{*}{ Rating } & \multicolumn{7}{|c|}{ Export volume } \\
\cline { 2 - 7 } & $\mathbf{2 0 1 1}$ & $\mathbf{2 0 1 2}$ & $\mathbf{2 0 1 3}$ & $\mathbf{2 0 1 4}$ & $\mathbf{2 0 1 5}$ & $\mathbf{2 0 1 6}$ \\
\hline 2010 & 0.57 & 0.57 & 0.58 & 0.58 & 0.58 & 0.58 \\
\hline 2011 & & 0.56 & 0.57 & 0.57 & 0.57 & 0.57 \\
\hline 2012 & & & 0.56 & 0.56 & 0.57 & 0.56 \\
\hline 2013 & & & & 0.56 & 0.56 & 0.55 \\
\hline 2014 & & & & & 0.56 & 0.56 \\
\hline 2015 & & & & & & 0.54 \\
\hline & & & \multicolumn{1}{|c|}{ Import volume } & \\
\hline Rating & 2011 & 2012 & 2013 & 2014 & 2015 & 2016 \\
\hline 2010 & -0.16 & -0.09 & 0.04 & 0.04 & 0.002 & -0.03 \\
\hline 2011 & & -0.06 & 0.06 & 0.06 & 0.004 & -0.03 \\
\hline 2012 & & & 0.05 & 0.06 & -0.003 & -0.05 \\
\hline 2013 & & & & 0.06 & -0.03 & -0.05 \\
\hline 2014 & & & & & -0.09 & -0.1 \\
\hline 2015 & & & & & & -0.1 \\
\hline
\end{tabular}

Looking at such developing of the international export-import volume indicators, we can put forward an assumption that country's tax policy ranking has more influence of country's exporting activities rather than on its importing activities. Formulated differently, this means that changes in national tax policy are often favorable for successful large businesses in a country, those that are actively selling their commodities to other countries. At the same time, those changes in a tax policy have not much influence on population consumption (of imported commodities).

Therefore, we conclude that even though the key goal of any serious change in taxation rules is often positioned as something good and useful for the country and its population in reality, such changes in taxation are mostly favoring largest national producers and their competitive advantages.

Taxation policy ranking - of any country - always belongs to the most influential factors in terms of impact on economic development. Indirectly, it also influences the dynamics of trade development (more specifically - import and export development). This is especially applicable to the economies in transit. Our calculations show that in the most needy countries the rate of taxation is usually the most influential indicator, while tax 
comfort and other taxation-related indicators seem to be of seriously less importance. At the same time, in the cases of underachieving countries and countries with median indicators, all parameters of taxation regimes seem to be of rather equal values.

Table 4. The impacts of tax regime parameters, by groups of countries (Calculated by the authors on the basis of the World Bank and Doing Business data).

\begin{tabular}{|c|c|c|c|c|}
\hline \multirow{3}{*}{ Groups of countries } & \multicolumn{4}{|c|}{ Tax regime parameters (100 is the maximum value) } \\
\hline & \multirow{2}{*}{$\begin{array}{l}\text { Overall } \\
\text { rating of the } \\
\text { group }\end{array}$} & \multicolumn{2}{|c|}{$\begin{array}{c}\text { Tax comfort } \\
\end{array}$} & \multirow[b]{2}{*}{$\begin{array}{c}\text { Average } \\
\text { taxation rate }\end{array}$} \\
\hline & & $\begin{array}{c}\text { Duration of all } \\
\text { formalities }\end{array}$ & $\begin{array}{l}\text { Quantity of } \\
\text { tax payments }\end{array}$ & \\
\hline Successful & 82 & 61 & 60 & 80 \\
\hline Developed & 75 & 41 & 67 & 65 \\
\hline Median & 97 & 80 & 100 & 99 \\
\hline Underachieving & 61 & 49 & 84 & 77 \\
\hline Needy & 100 & 77 & 89 & 96 \\
\hline
\end{tabular}

On a final note, we would like to emphasize that in case of successful and developed countries, macroeconomic indicators are primarily influenced by the rank of their tax systems and also by the rate of taxes overall. More details are provided in the tables above.

We can obviously track here that the most impressive effect on countries' trade and their economic development have national tax policies. However, this statement concerns only the three lower groups of countries and is not really applicable to richer countries.

On the other side, national tax policies seem to have not that much influence on exportimport activities and also for GDP growth per capita.

Curiously, in underachieving countries tax policy seems to have zero impact, literally.

Table 5. Correlation between tax regime parameters and the economic development indicators, by groups of countries.

\begin{tabular}{|c|c|c|c|c|}
\hline \multirow{2}{*}{$\begin{array}{c}\text { Country } \\
\text { groups }\end{array}$} & $\begin{array}{c}\text { Overall } \\
\text { tax } \\
\text { ranking }\end{array}$ & $\begin{array}{c}\text { Duration of all } \\
\text { formalities }\end{array}$ & $\begin{array}{c}\text { Quantity of } \\
\text { tax payments }\end{array}$ & $\begin{array}{c}\text { Average taxation } \\
\text { rate }\end{array}$ \\
\hline Successful & & & & 5 \\
\hline Developed & $1,2,3,5$ & 5 & & 3 \\
\hline Median & $3,5,7$ & $1,3,7$ & 7 & 5,7 \\
\hline Underachieving & & & & \\
\hline Needy & 1,3 & 7 & & $1,3,7$ \\
\hline
\end{tabular}

Where:

1- relative GDP

2- GDP growth in \%

3- GDP per capita

4- GDP per capita growth in \%

5- Export volume, absolute terms

6- Export growth in \%

7- Import volume, absolute terms

8- Import growth in \% 


\section{Concluding remarks}

We would like to position this study of ours as, on the one hand, statistical one, and on the other - as a study investigating macroeconomic impacts directly related to taxation and tax policy. Within such a framework, we put forward the following conclusions from this study:

First and foremost: country's national tax policy ranking (in Doing Business) proves to have a significant and long-term effect on GDP per capita. It also has a significant and long-term effect on national trade which is stronger for export and weaker for import.

Secondly, our study proves that taxation overall has a rather stimulating effect on macroeconomic development and country's trade attractiveness. However, this influence is also dependent upon national wellbeing indicators, additional economic parameters and trade infrastructure, inter alia.

As we have divided countries into groups for the purposes of our research, we also indirectly prove that influences of different taxation parameters are rather differentiated. This automatically means that state incentive measures aimed at boosting growth through changes in taxation must be adjusted as per particular country's rate of economic development.

In our opinion, such economic incentives should be adjusted in the following ways:

- In case of successful and developed countries the international ratings themselves serve, directly and indirectly, as part of incentives. They testify to all achievements of national economic policies in these countries. At the same time, we should not forget that the absolute majority of these countries also have quite high rates of taxation, and these high rates allow them invest further into own economic development and in their trade promotion in particular.

- In underachieving and needy countries, the size of tax rates is always ranked first in terms of importance, for both businesses and general population. At the same time, such parameters as taxation comfort, number of payments per year etc. are much less important. This is, however, not applicable to the group of countries which we've called "median" here - the countries with the most statistically average indicators. In such countries, the comfort of taxation procedures has quite solid stimulating powers. Moreover, in this particular group of countries economic development as such strongly depends upon liberalization of tax conditions.

- Stimulation of export trade through flexible tax rates is possible mostly in already successful and developed countries. Most of these countries are already using what is known as discriminatory tax rules providing solid trade preferences to the most active national exporters.

- Import is proved to be strongly dependent on a taxation system only in underachieving and needy countries. This indirectly proves that these two groups of countries are often experiencing lack of internal market propositions. In other words, proper stimulation through tax incentives may raise the level of national consumption, but we need to keep in mind here that this would be inevitably accompanied by various risks and threats for national producers.

- In three out of five country groups studied here, tax rating and tax comfort parameters have rather obvious influence on population wellbeing (which is traditionally measured through GDP per capita. Yet, these two indicators have significantly less influence on the growth of GDP and growth of GDP per capita.

Our conclusions presented above could and should be taken into account by governments in the course of national tax reforms and more specifically - while choosing the right tax instruments to be used as economic growth and trade (export/import) incentives. 


\section{References}

1. H. Pemberton, Policy learning and British governance in the 1960s (New York: Palgrave Macmillan, 2004)

2. S. Acharya, Trade Liberalization (Palgrave Macmillan, New York, 2015)

3. F.Widmalm, Public Choice 107(3), 199-219 (2001)

4. E. Balatskii, Studies on Russian Econ. Development 17(2), 204-208 (2006)

5. L. Sinevičienè, Entrepreneurship, Business and Economics 2, 283-298 (2016)

6. J. Vogel, Rich and Poor 15, 235-270 (2014)

7. C. Chaiboonsri, P. Chaitip, EUrASEANs 3(4), 26-38 (2017)

8. C. Keuschnigg, M. Dietz, International Tax and Public Finance 14(2), 191-221 (2007)

9. R. Hill, Public Choice 134(3), 419-427 (2008)

10. G. Scully, Public Choice 115(3), 299-312 (2003)

11. C. Echevarría, SERIEs 6(1), 43-72 (2015)

12. G. Marrero, J. of Economics 99(1), 29-51 (2010)

13. Y. Holynskyy, I. Onyusheva, EUrASEANs 1(14), 16-29 (2019)

14. A. Př́ivara, Transnational Marketing Journal 7(1), 59 - 72 (2019) 